Article

\title{
The Potential Effectiveness of Biochar Application to Reduce Soil Cd Bioavailability and Encourage Oak Seedling Growth
}

\author{
Elnaz Amirahmadi ${ }^{1}$, Seyed Mohammad Hojjati ${ }^{1}$ (D), Claudia Kammann ${ }^{2, *}$, \\ Mohammad Ghorbani ${ }^{3}$ and Pourya Biparva ${ }^{4}$ (D) \\ 1 Department of Forest Sciences and Engineering, Sari Agricultural Sciences and Natural Resources University, \\ Sari 4818168984, Iran; amirahmadielnaz@gmail.com (E.A.); s_m_hodjati@yahoo.com (S.M.H.) \\ 2 Department for Applied Ecology/Climate Change Research for Special Crops, Geisenheim University, \\ 65366 Geisenheim, Germany \\ 3 Department of Soil Science, Faculty of Agricultural Sciences, University of Guilan, Rasht 4199613776, Iran; \\ mghorbani0007@gmail.com \\ 4 Department of Basic Sciences, Sari Agricultural Sciences and Natural Resources University, \\ Sari 4818168984, Iran; p.biparva@sanru.ac.ir \\ * Correspondence: claudia.kammann@hs-gm.de
}

Received: 1 April 2020; Accepted: 2 May 2020; Published: 14 May 2020

\begin{abstract}
Today, it is very important to protect plants in soils contaminated with metals. We investigated the behavior of cadmium during the establishment of oak seedlings (Quercus castaneifolia C.A. Mey.) under biochar influence. This study was conducted in pots with loamy soil. Cadmium was added to soil at $0,10,30$, and $50 \mathrm{mg}$ per $\mathrm{kg}$ of soil, indicated by Control, Cd10, Cd30 and Cd50. Biochar was produced at $500-550{ }^{\circ} \mathrm{C}$ from rice husk and added at 1,3 , and $5 \%(\mathrm{wt} / \mathrm{wt}$ ) levels, indicated by B1, B3, B5, and mixed with soil at planting in three replications. Generally, increasing biochar rates had significant effects on seedling height, diameter, and biomass. This coincided with $\mathrm{Cd}$ immobilization in the contaminated soil which reflects a decrease in Cd concentrations in the plant bioavailability of $\mathrm{Cd}$. The tolerance index increased significantly, by $40.9 \%, 56 \%$, and $60.6 \%$ in B1, B3, and B5 with Cd50, respectively, compared to polluted soil. The percent of $\mathrm{Cd}$ removal efficiency for Cd50 was 21\%, 47\%, and 67\% in B1, B2, and B5, respectively. Our study highlights that biochar can reduce $\mathrm{Cd}$ bioavailability and improve the growth of oak seedlings in contaminated soil.
\end{abstract}

Keywords: seedling biomass; heavy metals; soil amelioration

\section{Introduction}

Anthropogenic activities that lead to producing landfill leachates, vehicle emissions, and the use of sewage water irrigation or pesticides can accumulate several metals in soils [1]. Recently, the concern for metal pollution in soil has increased and is recognized as a serious environmental problem [2,3]. Heavy metals remain in the soil for a long time and are irreversible [1]. Cadmium (Cd) is a toxic element that is non-essential for plant growth [2]. Large concentrations of $\mathrm{Cd}$ not only reduce growth and yield but also negatively affect plant physiological activities and can even cause plant death in higher concentrations [3,4]. Cadmium is dangerous because it is highly mobile in soil-plant systems, and it is highly toxic to plants [4]. Cadmium causes reductions in photosynthesis and subsequently in plant growth, and it can ultimately result in plant death [5]. Several biosynthesis processes have been prevented by excess $\mathrm{Cd}$ which disrupts the photosynthetic system in the plant. Cadmium stress, furthermore, induces necrosis, alters stomatal movements, ion homeostasis, and hence limits 
the availability of water and nutrients while it also affects the activities of several key enzymes and respiration in plants [6].

Applying organic amendments of plant or animal origin has the advantage of improving soil $\mathrm{C}$ sequestration and is an eco-friendly method for reducing the toxicity of metals [7]. Biochar is a soil modifier that is produced through pyrolysis of feedstock, such as agricultural residues, sawdust, wood chips, etc., under controlled oxygen conditions and temperature ranging from 350 to $750{ }^{\circ} \mathrm{C}$ [8]. Mohamed et al. [9] reported that biochars can retain nutrients and organic/inorganic contaminants. Biochar can trap metals and reduce their toxic effects due to the fact of its high cation exchange capacity (CEC), high $\mathrm{pH}$, and large effective surface area [10-13]. Biochar is generally rich in nutrients for the plant and when added, it increases them in the soil. [8]. Cui et al. [7] examined the effect of RHB on the soil properties of an acid sulfate soil and observed an increase in soil organic carbon (SOC), soil $\mathrm{pH}, \mathrm{CEC}$, phosphorus $(\mathrm{P})$, potassium $(\mathrm{K})$, and calcium $(\mathrm{Ca})$ and a decrease in exchangeable $\mathrm{Al}$ and soluble Fe.

Biochar can alter soil properties in such a way that it reduces the mobility of inorganic elements such as $\mathrm{Cd}$, subsequently increasing crop production but also nutrient retention in soil [14].

Quercus castaneifolia (Oak) is one of the major species with industrial valuable in the northern forests of Iran with a large distribution in the Caspian Hyrcanian mixed forests ( $36^{\circ} 16^{\prime} 17.9^{\prime \prime} \mathrm{N} 57^{\circ} 7^{\prime} 32.9^{\prime \prime}$ E). Oak seeds and leaves are used in pharmaceuticals, dyeing (as one of the natural dyes), and in the leather industry [15]. Unfortunately, human degradation in nature, such as mining, has caused the toxic metal contamination of Hyrcanian forest soil. Hence, protecting the Hyrcanian forest, as one of the UNESCO's World Heritage Sites, with valuable native species is necessary. Therefore, the use of biochar as a soil amendment can be a suitable approach to improve soil quality [16] and, at the same time, improve soil C sequestration.

The present study was therefore aimed at investigating the behavior of cadmium during the establishment of oak seedlings under biochar influence and performance, i.e., to examine if the use of biochar can serve as a tool for reclamation programs in mining areas.

\section{Materials and Methods}

\subsection{Plant and Soil Preparation}

The seedlings were obtained from Savadkoh Forest Nursery, Mazandaran $\left(36^{\circ} 16^{\prime} 17.9^{\prime \prime} \mathrm{N}\right.$ $\left.57^{\circ} 7^{\prime} 32.9^{\prime \prime} \mathrm{E}\right)$. Cadmium nitrate $\mathrm{Cd}\left(\mathrm{NO}_{3}\right)_{2}$ as $\mathrm{Cd}$ solution with deionized water was used to make contamination treatments [16]. Three concentrations of $\mathrm{Cd}$, including $0,10,30$, and $50 \mathrm{mg}$ per $\mathrm{kg}$ of soil, indicated by Control, Cd10, Cd30 and Cd50, were used in the experiment [17]. Cadmium levels were combined with three levels of biochar including 1\% (B1), 3\% (B2), and 5\% (B5) by weight. The experimental design is presented in Table 1. The pot experiment (resulting in 39 pots in total) was conducted at Sari Agricultural Science and Natural Resources University (SANRU), Mazandaran Province, Iran $\left(36^{\circ} 34^{\prime} 46.0^{\prime \prime} \mathrm{N} 53^{\circ} 11^{\prime} 30.4^{\prime \prime}\right.$ E). Each seedling was planted separately in $3 \mathrm{~kg}$ plastic pots on 20 March 2017.

Table 1. Experimental design for treatments.

\begin{tabular}{cccc}
\hline Treatments & Cd10 & Cd30 & Cd50 \\
\hline Polluted soil & Cd10 & Cd30 & Cd50 \\
Control & - & - & - \\
B1 & B1 + Cd10 & B1 + Cd30 & B1 + Cd50 \\
B3 & B3 + Cd10 & B3 + Cd30 & B3 + Cd50 \\
B5 & B5 + Cd10 & B5 + Cd30 & B5 + Cd50 \\
\hline
\end{tabular}

The properties of the soil used in this study are presented in Table 2. 
Table 2. Physicochemical characteristics (mean values \pm SE) of the forest nursery soil before the start of the pot experiment.

\begin{tabular}{cc}
\hline Physicochemical Parameter & Amount \\
\hline $\mathrm{pH}$ & $6.67 \pm 0.01$ \\
$\mathrm{EC}(\mathrm{dS} / \mathrm{m})$ & $819 \pm 1.08$ \\
$\mathrm{OC}(\%)$ & $6.53 \pm 0.23$ \\
$\mathrm{~N}(\%)$ & $0.082 \pm 0.003$ \\
$\mathrm{P}\left(\mathrm{mg} \mathrm{kg}^{-1}\right)$ & $29.17 \pm 0.66$ \\
$\mathrm{~K}\left(\mathrm{mg} \mathrm{kg}^{-1}\right)$ & $550.39 \pm 6.73$ \\
$\left.\mathrm{CEC}\left(\mathrm{cmol}^{+}\right) \mathrm{kg}^{-1}\right)$ & $7.97 \pm 0.25$ \\
Saturation Fluid Moisture $(\%)$ & $53.65 \pm 0.48$ \\
FC $(\%)$ & $32 \pm 0.52$ \\
$(\%$ Sand:Silt:Clay) & $50.1: 31.8: 18.1$ \\
Soil Texture & Loamy
\end{tabular}

EC: electrical conductivity, OC: organic matter, N: nitrogen, P: phosphorus, K: potassium, CEC: cation exchangeable capacity, FC: field capacity.

\subsection{Climatic Conditions and Irrigation}

Climatic conditions during the experimental period are shown in Figure 1. The Fifty-year average annual rainfall sum was $768 \mathrm{~mm}$, and the mean annual temperature was $19.3^{\circ} \mathrm{C}$.

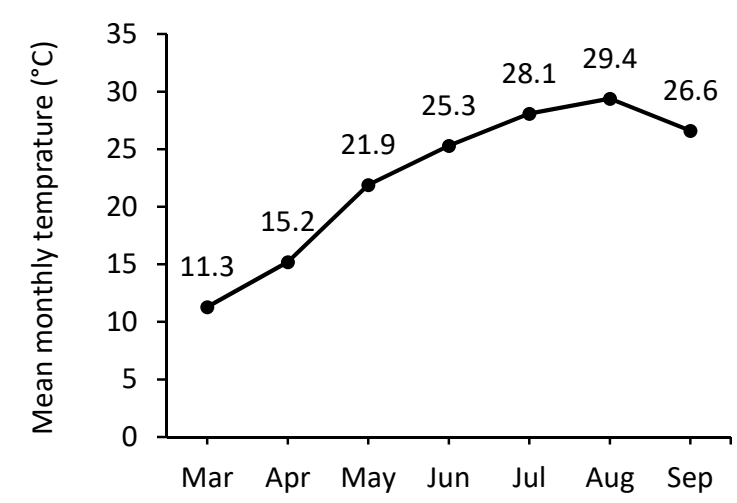

(a)

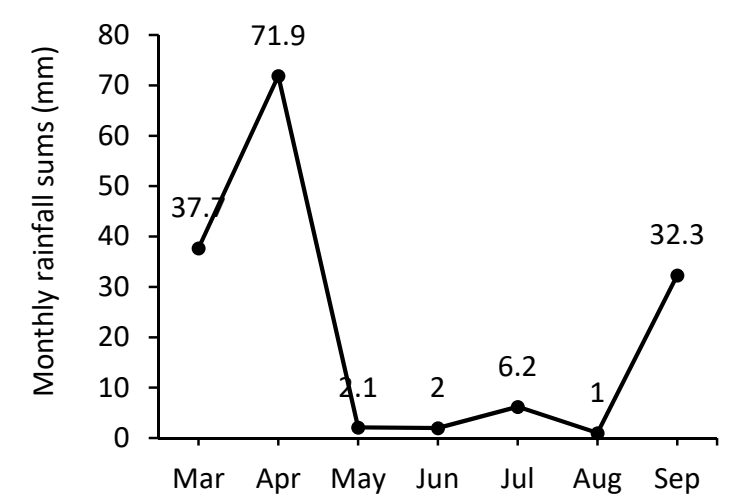

(b)

Figure 1. Climatic conditions during the experimental period: (a) mean monthly temperatures; (b) monthly rainfall sums.

We used tap water to irrigate the seedlings over the entire experiment. Irrigation was applied during the initial establishment of the experiment and, depending on the needs of the seedlings, two to three times a week where all tree seedlings received equal amounts of water. The amount of irrigation water was based on field capacity. Irrigation water for the whole period had neutral $\mathrm{pH}$ and concentrations of $\mathrm{Cd}(0.005 \mathrm{ppm})$.

\subsection{Feedstock and Properties of Biochar}

The biochar used in this study was produced from rice husk at $550{ }^{\circ} \mathrm{C} .[18,19]$. The biochar was characterized by elemental analysis (VarioMax CHNO Analyzer). Electrical conductivity and pH were measured using a 1:20 (biochar:water) solution [20]. The detailed chemical and physical characterizations of rice husk biochar are given in Table 3 . The amounts of $1 \%, 3 \%$, and $5 \%$ by weight [1] of rice husk biochar were homogeneously mixed with the soil one day before planting the seedlings. 
Table 3. Characteristics of rice husk biochar.

\begin{tabular}{|c|c|c|c|c|c|}
\hline Indicators & Value & Unit & Characterizations & Value & Unite \\
\hline $\mathrm{pH}$ & 8.14 & - & Oxygen & 0.001 & $\%$ \\
\hline $\mathrm{EC}$ & 359 & $\mathrm{dS} \mathrm{m}^{-1}$ & Phosphorous & 412 & $\mathrm{mg} \mathrm{kg}^{-1}$ \\
\hline $\mathrm{H} / \mathrm{C}$ & 0.36 & Molar ratio & Sodium & 76.1 & $\mathrm{mg} \mathrm{kg}^{-1}$ \\
\hline $\mathrm{C} / \mathrm{N}$ ratio & 101.7 & - & Potassium & 595 & $\mathrm{mg} \mathrm{kg}^{-1}$ \\
\hline CEC & 18.28 & $\operatorname{cmol}(+) \mathrm{kg}^{-1}$ & Calcium & 609 & $\mathrm{mg} \mathrm{kg}^{-1}$ \\
\hline Carbon & 68.03 & $\%$ & Magnesium & 163 & $\mathrm{mg} \mathrm{kg}^{-1}$ \\
\hline Nitrogen & 0.64 & $\%$ & Iron & 65 & $\mathrm{mg} \mathrm{kg}^{-1}$ \\
\hline Hydrogen & 25.12 & $\%$ & Zinc & 11.5 & $\mathrm{mg} \mathrm{kg}^{-1}$ \\
\hline
\end{tabular}

$\mathrm{EC}$, electrical conductivity; $\mathrm{CEC}$, cation exchangeable capacity; $\mathrm{H} / \mathrm{C}$, hydrogen/carbon ratio; $\mathrm{C} / \mathrm{N}$, carbon/nitrogen ratio.

\subsection{Seedling Height, Growth, and Biomass Analysis}

The height and diameter of the growing seedlings were measured once monthly, and the biomass of the seedlings was recorded after harvest at the end of the experiment (October 15, 2017). After the end of the experiment, the seedlings were washed with distilled water and then cut into leaves, stems, and roots to obtain a constant weight at $70^{\circ} \mathrm{C}$. In order to measure cadmium concentration in plant organs, a laboratory mixer (IKA Labortechnik M20) was used to powder the samples.

\subsection{Selected Soil Properties and Heavy Metal Detection}

The air-dried soil samples were analyzed for EC (by 1:5/soil:water suspension), $\mathrm{pH}$ (by 1:2.5/soil: water suspension), OC (by Walkley-Black method) [21], and CEC (by EDTA extraction method) [22]. The total nitrogen of the soil was measured by Kjeldahl and available phosphorus was measured by extraction with sodium bicarbonate method [23]. Measurement of soluble potassium in soil saturation extract was measured following the method of Helmke and Sparks [24]. The concentration of potassium in the extracts was measured using the Jenway PFP7 Flame Photometer.

Bioavailable cadmium was determined by the single extraction method [25]. To determine $\mathrm{Cd}$ concentrations in powdered plant material, $0.5 \mathrm{~g}$ of homogenized samples, $0.5 \mathrm{ml}$ of $37 \%$ hydrochloric acid, $9.0 \mathrm{~mL}$ of $69 \%$ nitric acid, and $1 \mathrm{~mL}$ of $30 \%$ hydrogen peroxide was added into the digestion vessel in an open system. All chemical materials were purchased from Sigma-Aldrich Corporation. After the digestion program, the $\mathrm{Cd}$ concentration in samples was analyzed by an atomic absorption spectrophotometer (PinAAcle 900F).

The tolerance index (TI\%) [26] and removal efficiency (RE\%) [27] were calculated by the following formulas:

$$
\mathrm{TI}(\%)=\left(1-\frac{\bar{X}_{\mathrm{f}}}{\mathrm{X}_{\mathrm{c}}}\right) \times 100
$$

where $\bar{X}_{\mathrm{f}}$ is the mean biomass in polluted soil, and $X_{c}$ is the mean biomass in the control.

$$
\operatorname{RE}(\%)=\left[1-\frac{C}{C_{0}}\right] \times 100
$$

where $C_{0}$ and $C$ are the initial and final extractable $C d$ concentrations in the soil, respectively.

\subsection{Data Analysis}

The experiment was based on one-factorial with three replications and the Student-Newman-Keuls (SNK)test was performed to test for significant differences among treatments $(p<0.05)$. The data's normal distribution test was evaluated using the Kolmogorov-Smirnov test and homogeneity of variance was checked using Levene's test. SPSS 23.0 was used to analyze the data. 


\section{Results}

\subsection{Seedling Growth}

Polluted soil significantly decreased the diameter of seedlings and height compared to the control $(p<0.05)$ (Figure 2). There was no significant difference in the diameter (Figure 2a) and height (Figure $2 \mathrm{~b}$ ) seedlings among treatments containing biochar and the control, except for treatment B1. However, no significant difference was observed between $\mathrm{Cd}$ levels in biochar treatments. But, in general, the polluted soil (without biochar) had a significantly lower diameter and height of seedlings than the biochar treatments.

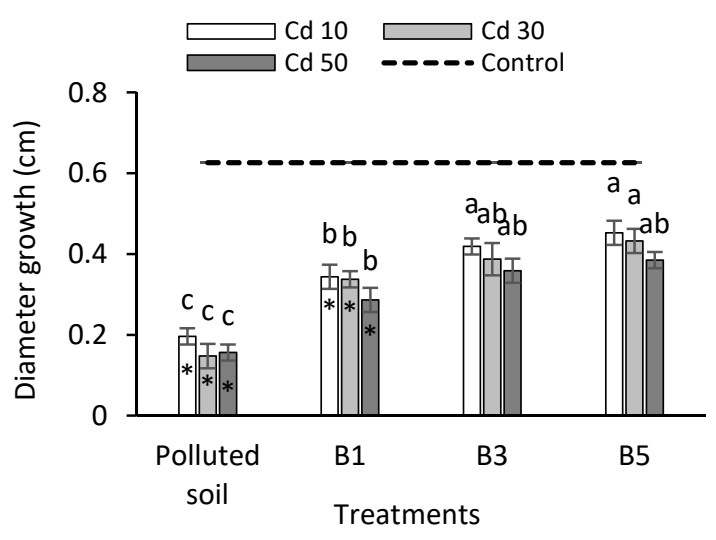

(a)

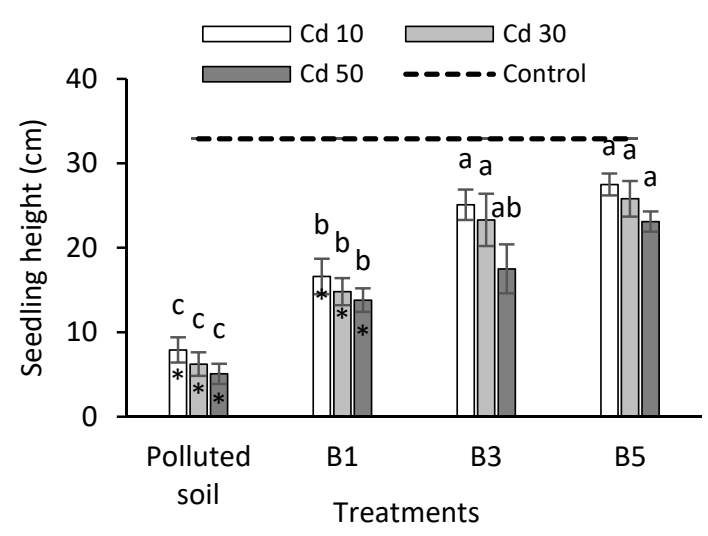

(b)

Figure 2. Effect of different levels of biochar on diameter growth and seedling height in oak seedlings at different levels of $\mathrm{Cd}$ contamination (means $+/-$ standard deviation): diameter growth (a) and seedling height (b). The dashed line represents the control (no biochar, no Cd), and the term "Polluted soil" indicates pots with $\mathrm{Cd}$ but without biochar. Different letters represent significant differences between treatments. The star indicates a significant difference between treatments and control.

\subsection{Seedling Biomass}

Cadmium treatments significantly decreased the leaf dry biomass, stem dry biomass, root dry biomass, and total dry biomass of the oak seedlings (Figure 3), stronger so with increasing Cd amendment level $(p<0.05)$, while biochar amendments increased the biomasses of all plant organs compared to the same pollution levels without the biochar amendment. Again, an amendment of 5\% of biochar always showed the best results at all contamination levels of $\mathrm{Cd}$.

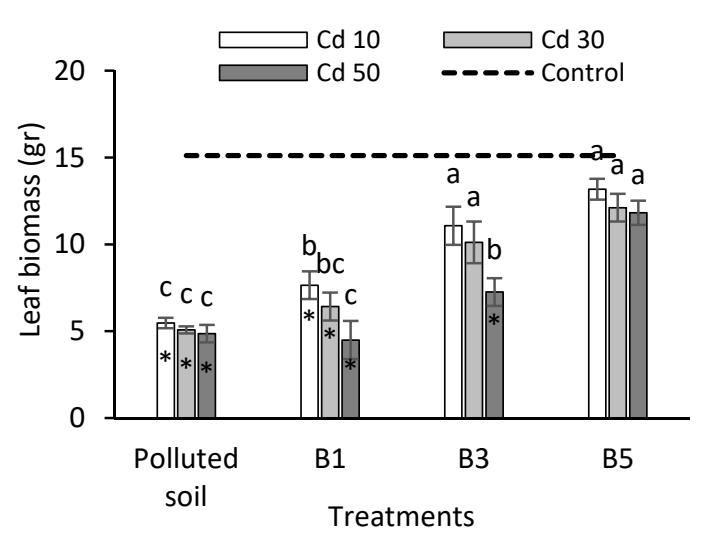

(a)

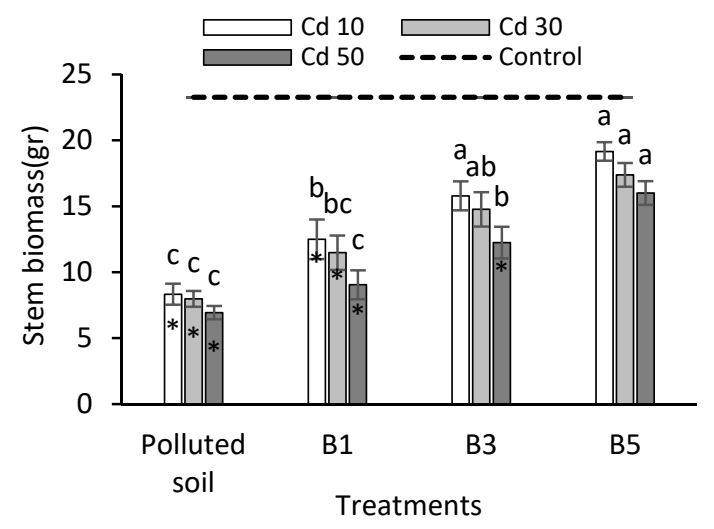

(b)

Figure 3. Cont. 


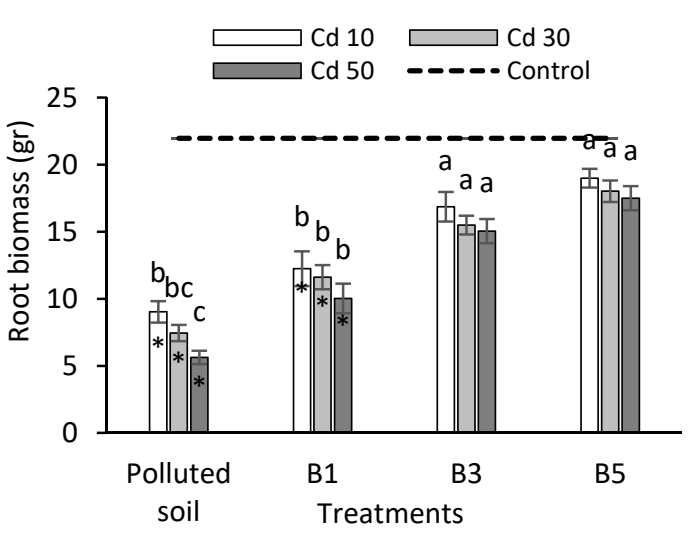

(c)

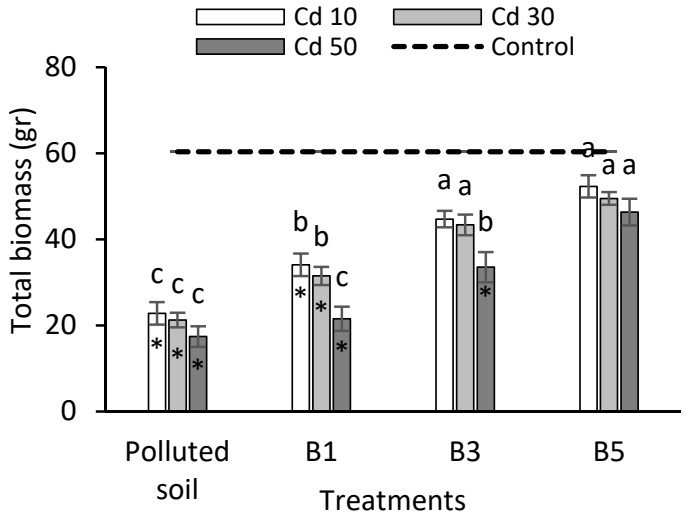

(d)

Figure 3. Effect of different levels of biochar on: (a) leaf biomass; (b) stem biomass; (c) root biomass; and (d) total biomass in oak seedlings at different levels of $\mathrm{Cd}$ contamination (bars represent means +/- one standard deviation). The dashed line represents the control (no biochar, no $\mathrm{Cd}$ ), and the term "Polluted soil" indicates pots with the Cd but without biochar. Different letters represent significant differences between treatments. The star indicates a significant difference between treatments and control.

\subsection{Chemical Soil Properties}

The results showed that only the main effect of biochar on soil properties was significant $(p<0.05)$. In the case of soil $\mathrm{pH}$, the application of $3 \%$ and $5 \%$ biochar showed significant increases than control (from 6.42 to 7.17 and 7.45, respectively) (Table 4). There was no significant difference in soil EC between biochar application rates and control (Table 4). B3 and B5 caused a significant increase $(p<0.05)$ in the OC content. Also, B3 and B5 significantly increased CEC $(p<0.05)$ by $9 \%$ and $20 \%$, respectively (Table 4). In the case of N, P, and K, all the treatments with biochar had significantly higher values than the control $(p<0.05)$.

Table 4. Soil chemical properties (mean values \pm SE) in presence of various percent of biochar.

\begin{tabular}{|c|c|c|c|c|c|c|c|}
\hline $\begin{array}{c}\text { Percent of } \\
\text { Biochar }\end{array}$ & $\mathrm{pH}$ & $\begin{array}{c}\text { EC } \\
\left(\mathrm{dS} \mathrm{m}^{-1}\right)\end{array}$ & OC $(\%)$ & $\begin{array}{c}\text { CEC } \\
\left(\mathrm{cmol}^{(+)}\right. \\
\left.\mathrm{kg}^{-1}\right)\end{array}$ & $\begin{array}{c}\mathrm{N} \\
\left(\mathrm{mg} \mathrm{kg}^{-1}\right)\end{array}$ & $\begin{array}{c}P \\
\left(\mathrm{mg} \mathrm{kg}^{-1}\right)\end{array}$ & $\begin{array}{c}\mathrm{K} \\
\left(\mathrm{mg} \mathrm{kg}^{-1}\right)\end{array}$ \\
\hline $\begin{array}{c}0 \\
\text { (Control) }\end{array}$ & $6.4 \pm 0.02^{b}$ & $0.31 \pm 0.02^{\mathrm{a}}$ & $1.1 \pm 0.02^{b}$ & $8.11 \pm 1.02^{c}$ & $0.15 \pm 0.01^{c}$ & $12.1 \pm 1.2^{\mathrm{c}}$ & $8.3 \pm 1.2^{c}$ \\
\hline $1 \%$ & $6.5 \pm 0.01^{b}$ & $0.27 \pm 0.05^{\mathrm{a}}$ & $1.2 \pm 0.04^{b}$ & $12.31 \pm 1.01^{b}$ & $0.4 \pm 0.03^{b}$ & $21.1 \pm 2.1^{b}$ & $15.4 \pm 1.1^{b}$ \\
\hline $3 \%$ & $7.17 \pm 0.03^{\mathrm{a}}$ & $0.26 \pm 0.02^{\mathrm{a}}$ & $1.57 \pm 0.01^{\mathrm{a}}$ & $13.35 \pm 1.03^{\mathrm{ab}}$ & $0.5 \pm 0.05^{b}$ & $35.5 \pm 3.3^{\mathrm{a}}$ & $29.5 \pm 1.3^{\mathrm{a}}$ \\
\hline $5 \%$ & $7.45 \pm 0.02^{\mathrm{a}}$ & $0.23 \pm 0.04^{\mathrm{a}}$ & $1.92 \pm 0.03^{\mathrm{a}}$ & $14.68 \pm 0.44^{\mathrm{a}}$ & $0.91 \pm 0.08^{\mathrm{a}}$ & $39.6 \pm 3.9^{\mathrm{a}}$ & $32.7 \pm 0.4^{\mathrm{a}}$ \\
\hline
\end{tabular}

EC: electrical conductivity; $\mathrm{OC}$, organic carbon; $\mathrm{CEC}$, cation exchangeable capacity. Mean values with the same letters were not significantly different $(p>0.05)$.

\subsection{Tolerance Index and Bioavailability}

Increasing the biochar rate increased the tolerance index at each $\mathrm{Cd}$ concentration level (Figure 4). The highest tolerance index was observed with B5 (Figure 4a). However, B1 and B3 also significantly improved the tolerance index, but $5 \%$ addition had the best effect at all levels of Cd pollution $(p<0.05)$. All biochar amendments decreased the bioavailability of $\mathrm{Cd}$, which was most significant at biochar amendment rates of $3 \%$ and $5 \%$ and partly significant at $1 \%$ biochar application $(p<0.05)$ (Figure $4 \mathrm{~b}$ ). The lowest bioavailability of $\mathrm{Cd}$ was generally observed at a biochar application rate of $5 \%$ (Figure $4 \mathrm{~b}$ ). Generally, the bioavailability of $\mathrm{Cd}$ in all treatments increased with an increasing Cd level. 


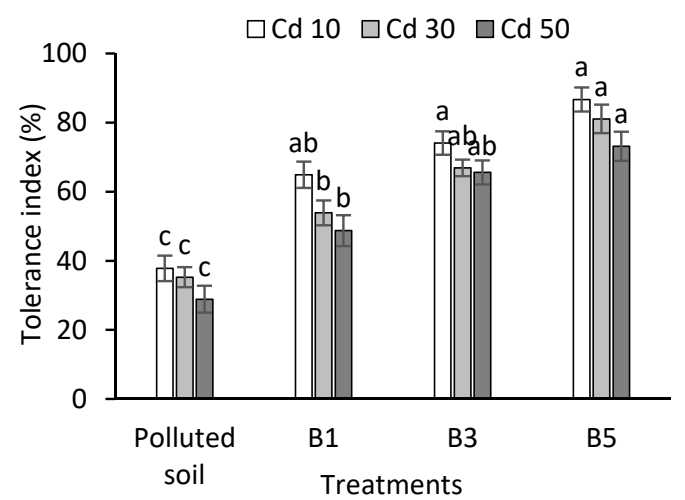

(a)

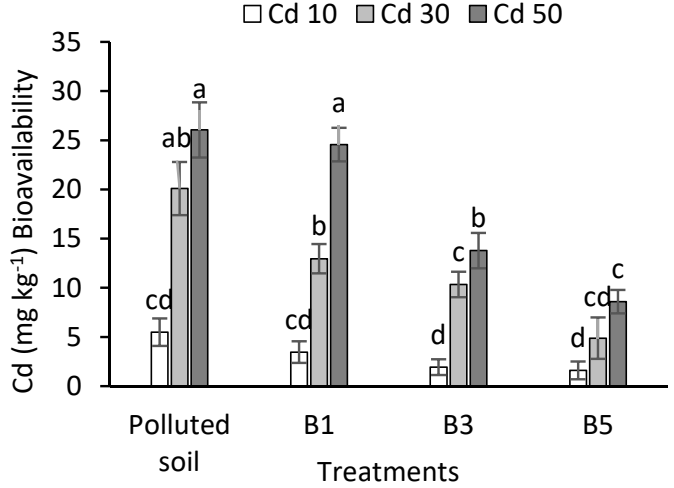

(b)

Figure 4. Effect of different levels of biochar on: (a) tolerance index and (b) bioavailability of Cd in oak seedlings at different levels of Cd contamination (means +/- one standard error). The term "Polluted soil" indicates pots with the $\mathrm{Cd}$ but without biochar. Different letters represent significant differences between treatments.

\subsection{Cadmium in Plant Tissues}

Higher soil Cd concentrations significantly caused greater $\mathrm{Cd}$ concentrations in all plant organs (Figure 5). However, using biochar amendments decreased the concentration of $\mathrm{Cd}$ in plant tissues significantly $(\mathrm{p}<0.05)$ compared to the control at the same $\mathrm{Cd}$ pollution level which was the most pronounced in the leaves (Figure 5a) and the least pronounced (although still mostly significant) in the roots (Figure 5c). Again, B5 treatment caused the lowest concentration of Cd in plant tissues in all pollution levels of $\mathrm{Cd}$.

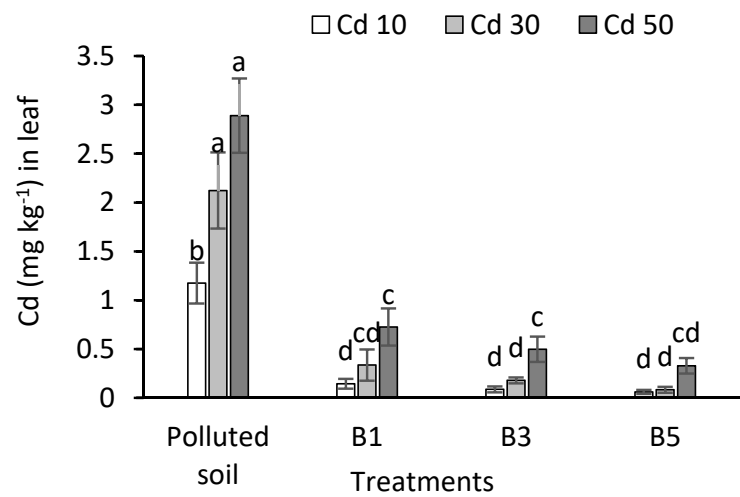

(a)

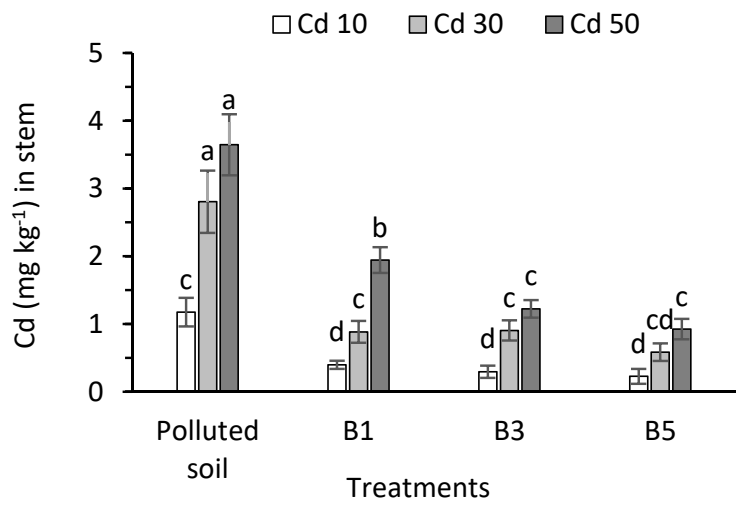

(b)

Figure 5. Cont. 


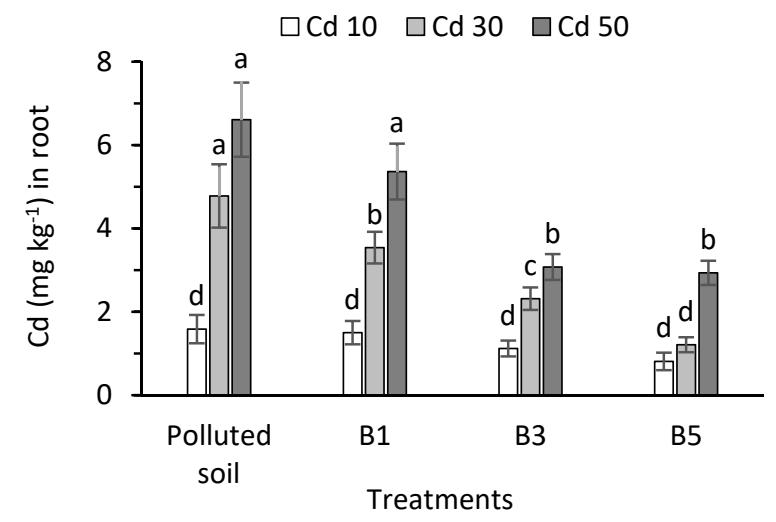

(c)

Figure 5. Effect of different levels of biochar on the concentrations of (a) Cd in leaves; (b) Cd in the stem; and (c) Cd in root tissue in oak seedlings at different levels of Cd contamination (means +/- one standard error). The term "Polluted soil" indicates pots with the Cd but without biochar. Different letters represent significant differences between treatments.

\subsection{Cadmium Removal Efficiency}

Increasing the amount of biochar amendment significantly decreased the Cd removal efficiency throughout all $\mathrm{Cd}$ pollution levels. The maximum removal efficiency for all $\mathrm{Cd}$ treatments was achieved with B5, while the minimum removal efficiency was observed with B1 (Figure 6).

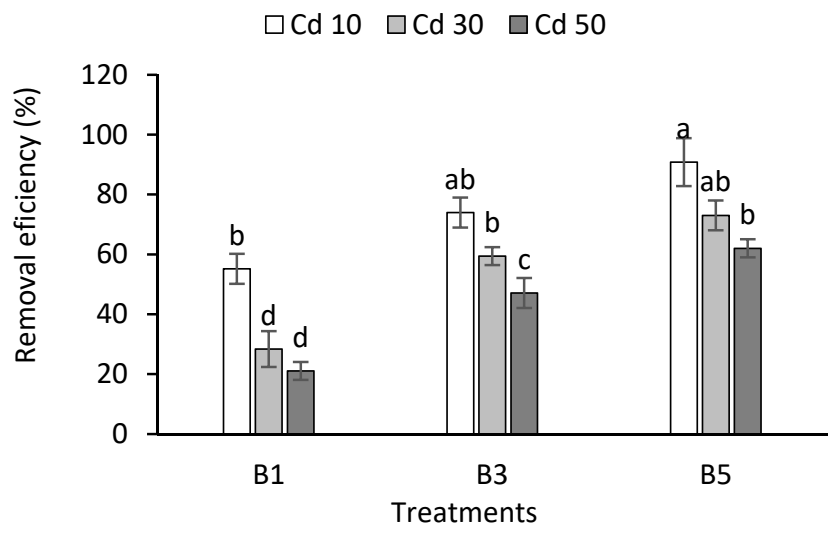

Figure 6. Effect of different levels of biochar on the removal efficiency in oak seedlings at different levels of $\mathrm{Cd}$ contamination (means $+/-$ one standard error). Different letters represent significant differences between treatments.

With increasing biochar application level, Cd removal efficiency increased (Figure 7). 


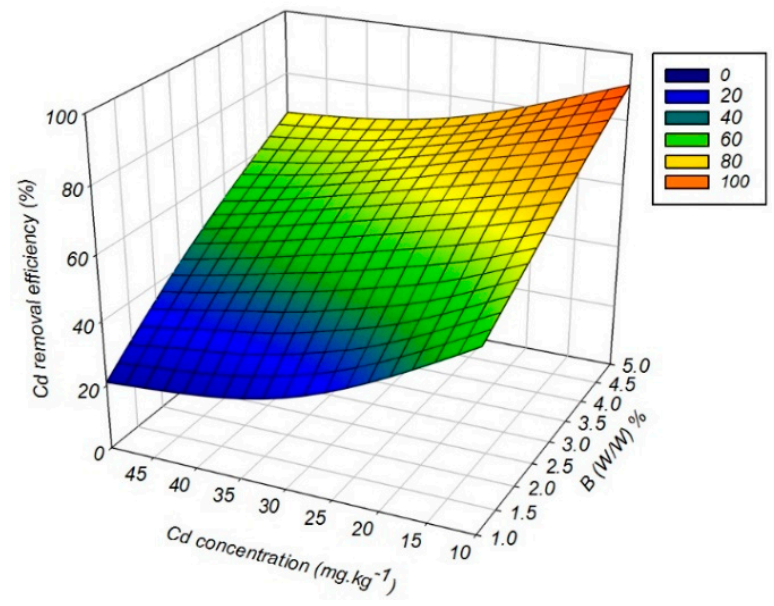

Figure 7. Cadmium removal efficiency as a function of $\mathrm{Cd}$ contamination level and biochar amendment level.

\section{Discussion}

As expected, increasing levels of $\mathrm{Cd}$ treatments significantly reduced plant diameter, height growth, and seedlings biomass (Figures 2 and 3). Kukier and Chaney [28] reported that Cd, by disrupting nutrient absorption and photosynthesis, reduces plant growth and biomass production. Similar results were reported by other researches [29,30].

In general, biochar had a positive effect on seedling growth and establishment, alleviating $\mathrm{Cd}$-induced reductions in growth and development. Compared to biochar-free $\mathrm{Cd}$-contaminated soils, biochar application increased seedling height and diameter, root, shoot, and leaf growth and hence the tolerance index mainly by reducing the amount of $\mathrm{Cd}$ that could be taken up by the seedlings [31]. Cation exchange capacity is one of the key factors in soil conditions that provides a high level of nutritional cations for plant use [6]. The natural CEC of the soil was $7.97 \mathrm{cmol}^{(+)} \mathrm{kg}^{-1}$ before adding biochar (Table 2) and which was increased by adding B1, B3, and B5 to 12.31, 13.65, and $14.68 \mathrm{cmol}^{(+)} \mathrm{kg}^{-1}$, respectively (Table 4). This means an increase in the provision of cations in the soil for plant roots [32]. On the other hand, the high efficiency of biochar to adsorb metals and then increase plant growth [33] comes from its high porosity, a high number of functional groups, and high $\mathrm{pH}[34,35]$. Also, the mineral components in biochar, including phosphates and carbonates, can precipitate with metals and reduce their bioavailability $[36,37]$. The results of the meta-analysis by Chen et al. [38] claimed that increases in the $\mathrm{pH}$ and CEC of soils are the main mechanisms of biochar in reducing metal bioavailability. The soil $\mathrm{pH}$ controls the solubility and bioavailability of the chemicals in the soil, both nutrients and pollutants, and therefore influences soil quality, crop productivity, and environment pollution [39]. In this study, the soil $\mathrm{pH}$ was slightly acidic (6.67). The bioavailability of micronutrients was higher than that of neutral-alkaline soils (soil $\mathrm{pH}>7$ ), enhancing crop productivity [40], but at the same time, the solubility of heavy metals and some of these nutrients may pass the critical level of environmental toxicity in these soils. Biochars, in general, have the potential and event priority to substitute lime for improving the properties of acidic soils and, therefore, enhanced plant growth [41]. Perhaps, the increase in pH (16\%) and CEC (20\%) compared to the control in the present investigation were related to the same reason.

Besides that, the use of biochar had positive effects on soil macronutrients (Table 4). Biochars, generally, are rich in plant nutrients (except for $\mathrm{N}$ when woody) and when added to soil, they usually increase soil fertility [30]. Masulili et al. [42] examined the effect of rice husk biochar on the soil properties of an acid sulfate soil and observed an increase in SOC, soil pH, CEC, N, P, K, and Ca and a decrease in exchangeable $\mathrm{Al}$ and soluble Fe. However, the amount of $\mathrm{Mg}$ and $\mathrm{Na}$ remained unaffected by biochar. Singh et al. [43] reported a significant increase in the water holding capacity, total C, N, and $\mathrm{P}$, and soil moisture content. 
According to the results, the addition of biochar significantly reduced the bioavailability of $\mathrm{Cd}$ in the soil (Figure 4), and the $\mathrm{Cd}$ concentrations in soil decreased with increasing biochar application levels (although not linearly). A reduced bioavailability of metals with biochar has been reported previously for $\mathrm{Cd}$ contamination in sandy soil to maize [44] and $\mathrm{Cu}$ toxicity in sandy soil to quinoa seedlings [45]. Several researchers $[38,46,47]$ showed that biochar application reduced the concentration of metals and improved the condition of the plant and soil in terms of contamination because of its high surface area and CEC, as well as the presence of carboxyl, phenolic, hydroxyl, and other functional groups that contain superficial oxygen. On the other hand, the application of biochar often increases the $\mathrm{pH}$ value significantly, as shown by Lucchini et al. [48], and could hence decrease the mobility of the Cd.

The mechanism for this is that biochar increases the adsorption capacity of cations by increasing the negative charge on the soil surface [49-51]. Also, biochar is a porous substrate with a high surface area for the absorption of heavy metals and the formation of a complex with soluble organic carbon which immobilizes heavy metals [52]. According to Table 4, soil containing treatment B5 had the highest amount of organic carbon (1.92\%). Similar results were reported by other studies [53,54].

Our findings show that the addition of biochar significantly reduced the concentration of $\mathrm{Cd}$ in the tissue of plants (Figure 5) as reported previously for maize by Liu et al. [3]. The low concentration of metals in the plant was directly related to the loss of metal bioavailability in the soil [38]. The $\mathrm{pH}$ of soil with the B5 treatment increased by 1.03 in the soil over the control. This increase may be related to $\mathrm{pH}=8.14$ in biochar. Li et al. [54] stated that the high $\mathrm{pH}$ of biochar is due to the dominance of carbonates and organic anions over ash. Generally, data on $\mathrm{Cd}$ accumulation in roots, stems, and leaves shows that $\mathrm{Cd}$ accumulates in the roots more than other plant organs (Figure 5), a strategy that was also employed by quinoa seedlings regarding $\mathrm{Cu}$ toxicity [45]. Due to the toxicity of $\mathrm{Cd}$ to cytosol in its free form, plant cells likely try to fix it at the root by ways such as attaching it to the cell wall [55], storing it in vacuoles [56], and chelating it with phytochelatin [55], thus reducing its toxicity. The result will be a low transfer of $\mathrm{Cd}$ to the upper plant organs.

As shown in Figure 6, increasing the level of biochar application decreased the cadmium concentration at all levels. Adding biochar to the soil will have a series of incremental consecutive consequences, including porosity, surface reactive sites, contact between $\mathrm{Cd}$ and biochar, the redox potential, and the removal efficiency of Cd [57] (Figure 7). The high CEC of biochar is directly related to its specific surface area and high porosity and therefore the CEC of soil can be increased (Table 4) [53]. The increase in negative charge due to the biochar oxidation is also a reason for the high biochar CEC [58].

\section{Conclusions}

In this study, biochar amendments of rice husk biochar clearly reduced the bioavailability of cadmium in increasingly contaminated soil, alleviating the negative impact of the Cd pollution on seedling physiology and growth. The plant tolerance index for the highest Cd rate of $50 \mathrm{mg} \mathrm{kg} \mathrm{g}^{-1}$ increased significantly by $40.9 \%, 56 \%$, and $60.6 \%$ with rice husk biochar addition rates of $1 \%, 3 \%$, and $5 \%$, respectively. Therefore, biochar application in Cd-contaminated oak forests can be a viable solution for oak seedling establishment. It remains to be tested if contaminations with other cationic heavy metals will be likewise remediated by biochar use, but the encouraging results obtained in this study, combined with that of other studies [44,45], call for the real-world first field testing in contaminated mining soils in Iran.

Author Contributions: Conceptualization, E.A.; Methodology, S.M.H. and C.K.; Software, E.A. and M.G.; Validation, S.M.H. and C.K.; Formal Analysis, E.A. and M.G.; Investigation, E.A. and S.M.H; Resources, P.B.; Data Curation, E.A. and M.G.; Writing-Original Draft Preparation, E.A.; Writing-Review and Editing, E.A., S.M.H. and C.K.; Supervision, S.M.H.; Project Administration, E.A. All authors have read and agreed to the published version of the manuscript.

Funding: This research received no external funding. 
Acknowledgments: The authors sincerely thank the Geisenheim University in Germany for providing the facilities and resources, e.g., extended literature analyses, for this research.

Conflicts of Interest: The authors declare no conflict of interest.

\section{References}

1. Seneviratne, M.; Weerasundara, L.; Ok, Y.S.; Rinklebe, J.; Vithanage, M. Phytotoxicity attenuation in Vigna radiata under heavy metal stress at the presence of biochar and N fixing bacteria. J. Environ. Manag. 2017, 186, 293-300. [CrossRef] [PubMed]

2. Al-Wabel, M.I.; Usman, A.R.; El-Naggar, A.H.; Aly, A.A.; Ibrahim, H.M.; Elmaghraby, S.; Al-Omran, A. Conocarpus biochar as a soil amendment for reducing heavy metal availability and uptake by maize plants. Saudi J. Biol. Sci. 2015, 22, 503-511. [CrossRef] [PubMed]

3. Liu, L.; Li, J.; Yue, F.; Yan, X.; Wang, F.; Bloszies, S.; Wang, Y. Effects of arbuscular mycorrhizal inoculation and biochar amendment on maize growth, cadmium uptake and soil cadmium speciation in Cd-contaminated soil. Chemosphere 2018, 194, 495-503. [CrossRef] [PubMed]

4. Soudek, P.; Valseca, I.R.; Petrová, Š.; Song, J.; Vaněk, T. Characteristics of different types of biochar and effects on the toxicity of heavy metals to germinating sorghum seeds. J. Geochem. Explor. 2017, 182, $157-165$. [CrossRef]

5. Abbas, T.; Rizwan, M.; Ali, S.; Adrees, M.; Mahmood, A.; Zia-ur-Rehman, M.; Ibrahim, M.; Arshad, M.; Qayyum, M.F. Biochar application increased the growth and yield and reduced cadmium in drought stressed wheat grown in an aged contaminated soil. Ecotoxicol. Environ. 2018, 148, 825-833. [CrossRef]

6. Tekdal, D.; Cetiner, S. Investigation of the effects of salt $(\mathrm{NaCl})$ stress and cadmium (cd) toxicity on growth and mineral acquisition of Vuralia turcica. S. Afr. J. Bot. 2018, 118, 274-279. [CrossRef]

7. Cui, L.; Pan, G.; Li, L.; Bian, R.; Liu, X.; Yan, J.; Quan, G.; Ding, C.; Chen, T.; Liu, Y.; et al. Continuous immobilization of cadmium and lead in biochar amended contaminated paddy soil: A five-year field experiment. Ecol. Eng. 2016, 93, 1-8. [CrossRef]

8. Lehmann, J.; Rillig, M.C.; Thies, J.; Masiello, C.A.; Hockaday, W.C.; Crowley, D. Biochar effects on soil biota: A review. Soil. Biol. Biochem. 2011, 43, 1812-1836. [CrossRef]

9. Mohamed, B.A.; Ellis, N.; Kim, C.S.; Bi, X. The role of tailored biochar in increasing plant growth, and reducing bioavailability, phytotoxicity, and uptake of heavy metals in contaminated soil. Environ. Pollut. 2017, 230, 329-338. [CrossRef]

10. Ippolito, J.A.; Laird, D.A.; Busscher, W.J. Environmental benefits of biochar. J. Environ. Qual. 2012, 41, 967-972. [CrossRef]

11. Ramzani, P.M.A.; Coyne, M.S.; Anjum, S.; Iqbal, M. In situ immobilization of Cd by organic amendments and their effect on antioxidant enzyme defense mechanism in mung bean (Vigna radiata L.) seedlings. Plant. Physiol. Bioch. 2017, 118, 561-570. [CrossRef] [PubMed]

12. Ghorbani, M.; Amirahmadi, E. Effect of rice husk Biochar (RHB) on some of chemical properties of an acidic soil and the absorption of some nutrients. J. Appl. Sci. Environ. Manag. 2018, 22, 313-317. [CrossRef]

13. Alobwede, E.; Leake, J.R.; Pandhal, J. Circular economy fertilization: Testing micro and macro algal species as soil improvers and nutrient sources for crop production in greenhouse and field conditions. Geoderma 2019, 334, 113-123. [CrossRef]

14. Fellet, G.; Marmiroli, M.; Marchiol, L. Elements uptake by metal accumulator species grown on mine tailings amended with three types of biochar. Sci. Total Environ. 2014, 468, 598-608. [CrossRef] [PubMed]

15. Sabeti, H. Forests, Trees and Shrubs of Iran; Ministry of Agriculture and Natural Resources: Iran, Tehran, 1976.

16. Tafazoli, M.; Hojjati, S.M.; Biparva, P.; Kooch, Y.; Lamersdorf, N. Reduction of soil heavy metal bioavailability by nanoparticles and cellulosic wastes improved the biomass of tree seedlings. J. Plant. Nutr. Soil. Sci. 2017, 180, 683-693. [CrossRef]

17. Zhang, Z.; Solaiman, Z.M.; Meney, K.; Murphy, D.V.; Rengel, Z. Biochars immobilize soil cadmium, but do not improve growth of emergent wetland species Juncus subsecundus in cadmium-contaminated soil. J. Soil. Sediment. 2013, 13, 140-151. [CrossRef]

18. Gamage, D.N.V.; Mapa, R.B.; Dharmakeerthi, R.S.; Biswas, A. Effect of rice-husk biochar on selected soil properties in tropical Alfisols. Soil Res. 2016, 54, 302. [CrossRef] 
19. Ghorbani, M.; Asadi, H.; Abrishamkesh, S. Effects of rice husk biochar on selected soil properties and nitrate leaching in loamy sand and clay soil. Int. Soil Water Conserv. Res. 2019, 7, 258-265. [CrossRef]

20. Rajkovich, S.; Enders, A.; Hanley, K.; Hyland, C.; Zimmerman, A.R.; Lehmann, J. Corn growth and nitrogen nutrition after additions of biochars with varying properties to a temperate soil. Biol. Fertil. Soils 2012, 48, 271-284. [CrossRef]

21. Chan, Y.C.; Vowles, P.D.; McTainsh, G.H.; Simpson, R.W.; Cohen, D.D.; Bailey, G.M. Use of a modified Walkley-Black method to determine the organic and elemental carbon content of urban aerosols collected on glass fibre filters. Chemosphere 1995, 31, 4403-4411. [CrossRef]

22. Sumner, M.E.; Miller, W.P. Cation exchange capacity and exchange coefficients. Methods Soil Anal. Part 3 Chem. Methods 1996, 5, 1201-1229.

23. Helmke, P.; Sparks, D. Lithium, sodium, potassium, rubidium, and cesium. Methods Soil Anal. Part 3 Chem. Methods 1996, 551-740. [CrossRef]

24. Olsen, S.R. Estimation of Available Phosphorus in Soils by Extraction with Sodium Bicarbonate; United States Department of Agriculture: Washington, DC, USA, 1954.

25. Quevauviller, P.; Rauret, G.; López-Sánchez, J.F.; Rubio, R.; Ure, A.; Muntau, H. Certification of trace metal extractable contents in a sediment reference material (CRM 601) following a three-step sequential extraction procedure. Sci. Total. Environ. 1997, 205, 223-234. [CrossRef]

26. Landberg, T.; Greger, M. Differences in oxidative stress in heavy metal resistant and sensitive clones of Salix viminalis. J. Plant Physiol. 2002, 159, 69-75. [CrossRef]

27. Poo, K.M.; Son, E.B.; Chang, J.S.; Ren, X.; Choi, Y.J.; Chae, K.J. Biochars derived from wasted marine macro-algae (Saccharina japonica and Sargassum fusiforme) and their potential for heavy metal removal in aqueous solution. J. Environ. Manag. 2018, 206, 364-372. [CrossRef]

28. Kukier, U.; Chaney, R.L. In situ remediation of nickel phytotoxicity for different plant species. J. Plant Nutr. 2004, 27, 465-495. [CrossRef]

29. Bolan, N.; Kunhikrishnan, A.; Thangarajan, R.; Kumpiene, J.; Park, J.; Makino, T.; Kirkham, M.B.; Scheckel, K. Remediation of heavy metal (loid) s contaminated soils-to mobilize or to immobilize? J. Hazard. Mater. 2014, 266, 141-166. [CrossRef]

30. Quintela-Sabaris, C.; Marchand, L.; Kidd, P.S.; Friesl-Hanl, W.; Puschenreiter, M.; Kumpiene, J.; Mueller, I.; Neu, S.; Janssen, J.; Vangronsveld, J.; et al. Assessing phytotoxicity of trace element-contaminated soils phytomanaged with gentle remediation options at ten European field trials. Sci. Total. Environ. 2017, 599, 1388-1398. [CrossRef]

31. Ramzani, P.M.A.; Iqbal, M.; Kausar, S.; Ali, S.; Rizwan, M.; Virk, Z.A. Effect of different amendments on rice (Oryza sativa L.) growth, yield, nutrient uptake and grain quality in Ni-contaminated soil. Environ. Sci. Pollut. Res. 2016, 23, 18585-18595. [CrossRef]

32. Nahar, K.; Rahman, M.; Hasanuzzaman, M.; Alam, M.M.; Rahman, A.; Suzuki, T.; Fujita, M. Physiological and biochemical mechanisms of spermine-induced cadmium stress tolerance in mung bean (Vigna radiata $\mathrm{L}$.) seedlings. Environ. Sci. Pollut. Res. 2016, 23, 21206-21218. [CrossRef]

33. Xu, G.; Shao, H.B.; Sun, J.N. What is more important for enhancing nutrient bioavailability with biochar application into a sandy soil: Direct or indirect mechanism. Ecol. Eng. 2013, 52, 119-124. [CrossRef]

34. Zhang, X.; Wang, H.; He, L.; Lu, K.; Sarmah, A.; Li, J.; Huang, H. Using biochar for remediation of soils contaminated with heavy metals and organic pollutants. Environ. Sci. Pollut. Res. 2013, 20, 8472-8483. [CrossRef] [PubMed]

35. Wang, Y.; Wang, Z.L.; Zhang, Q.; Hu, N.; Li, Z.; Lou, Y.; Li, Y.; Xue, D.; Chen, Y.; Wu, C.; et al. Long-term effects of nitrogen fertilization on aggregation and localization of carbon, nitrogen and microbial activities in soil. Sci. Total. Environ. 2018, 624, 1131-1139. [CrossRef]

36. Cao, X.; Ma, L.; Gao, B.; Harris, W. Dairy-manure derived biochar effectively sorbs lead and atrazine. Environ. Sci. Technol. 2009, 43, 3285-3291. [CrossRef] [PubMed]

37. Kumar, M.; Rajput, T.B.S.; Kumar, R.; Patel, N. Water and nitrate dynamics in baby corn (Zea mays L.) under different fertigation frequencies and operating pressures in semiarid region of India. Agric. Water Manag. 2016, 163, 263-274. [CrossRef]

38. Chen, D.; Liu, X.; Bian, R.; Cheng, K.; Zhang, X.; Zheng, J.; Joseph, S.; Crowley, D.; Pan, G.; Li, L. Effects of biochar on availability and plant uptake of heavy metals-A meta-analysis. J. Environ. Manag. 2018, 222, 76-85. [CrossRef] 
39. Weil, R.R.; Brady, N.C. The Nature and Properties of Soils, 15th ed.; Prentice Hall: Upper Saddle River, NJ, USA, 2016.

40. Lončarić, Z.; Karalić, K.; Popović, B.; Rastija, D.; Vukobratović, M. Total and plant available micronutrients in acidic and calcareous soils in Croatia. Cereal. Res. Commun. 2008, 36, 331-334.

41. Wu, S.; Zhang, Y.; Tan, Q.; Sun, X.; Wei, W.; Hu, C. Biochar is superior to lime in improving acidic soil properties and fruit quality of Satsuma mandarin. Sci. Total. Environ. 2020, 714, 136722. [CrossRef]

42. Masulili, A.; Utomo, W.H.; Syechfani, M. Rice husk biochar for rice based cropping system in acid soil 1. The characteristics of rice husk biochar and its influence on the properties of acid sulfate soils and rice growth in West Kalimantan, Indonesia. J. Agric. Sci. 2010, 2, 39. [CrossRef]

43. Singh, C.; Tiwari, S.; Gupta, V.K.; Singh, J.S. The effect of rice husk biochar on soil nutrient status, microbial biomass and paddy productivity of nutrient poor agriculture soils. Catena 2018, 171, 485-493. [CrossRef]

44. Namgay, T.; Singh, B.; Singh, B.P. Influence of biochar application to soil on the availability of $\mathrm{As}, \mathrm{Cd}, \mathrm{Cu}, \mathrm{Pb}$, and Zn to maize (Zea mays L.). Soil Res. 2010, 48, 638-647. [CrossRef]

45. Buss, W.; Kammann, C.; Koyro, H.W. Biochar reduces copper toxicity in Chenopodium quinoa Willd. in a sandy soil. J. Environ. Qual. 2012, 41, 1157-1165. [CrossRef] [PubMed]

46. Beesley, L.E.; Moreno-Jiménez, L.; Jose, J.L.; Gomez-Eyles, E.; Harris, B.; Robinson, B.; Sizmur, T. A review of biochars' potential role in the remediation, revegetation and restoration of contaminated soils. Environ. Pollut. 2011, 159, 3269-3282. [CrossRef] [PubMed]

47. Carter, S.; Shackley, S.; Sohi, S.; Suy, T.B.; Haefele, S. The Impact of Biochar Application on Soil Properties and Plant Growth of Pot Grown Lettuce (Lactuca sativa) and Cabbage (Brassica chinensis). Agronomy 2013, 3, 404-418. [CrossRef]

48. Lucchini, P.; Quilliam, R.S.; DeLuca, T.H.; Vamerali, T.; Jones, D.L. Does biochar application alter heavy metal dynamics in agricultural soil? Agric. Ecosyst. Environ. 2014, 184, 149-157. [CrossRef]

49. Lindsay, W.L. Chemical Equilibria in Soils; John Wiley \& Sons Ltd.: Hoboken, NJ, USA, 1979.

50. McBride, M.; Sauve, S.; Hendershot, W. Solubility control of $\mathrm{Cu}, \mathrm{Zn}, \mathrm{Cd}$ and $\mathrm{Pb}$ in contaminated soils. Eur. J. Soil Sci. 1997, 48, 337-346. [CrossRef]

51. Ma, L.; $\mathrm{Xu}, \mathrm{R} . ;$ Jiang, J. Adsorption and desorption of $\mathrm{Cu}$ (II) and $\mathrm{Pb}$ (II) in paddy soils cultivated for various years in the subtropical China. Int. J. Environ. Sci. 2010, 22, 689-695. [CrossRef]

52. Shen, X.; Huang, D.Y.; Ren, X.F.; Zhu, H.H.; Wang, S.; Xu, C.; He, Y.B.; Luo, Z.C.; Zhu, Q.H. Phytoavailability of $\mathrm{Cd}$ and $\mathrm{Pb}$ in crop straw biochar-amended soil is related to the heavy metal content of both biochar and soil. J. Environ. Manag. 2016, 168, 245-251. [CrossRef]

53. Jien, S.H.; Wang, C.S. Effects of biochar on soil properties and erosion potential in a highly weathered soil. Catena 2013, 110, 225-233. [CrossRef]

54. Li, J.H.; Lv, G.H.; Bai, W.B.; Liu, Q.; Zhang, Y.C.; Song, J.Q. Modification and use of biochar from wheat straw (Triticum aestivum L.) for nitrate and phosphate removal from water. Desalin. Water Treat 2016, 57, 4681-4693.

55. Gong, J.; David, A.; Julian, I. Longdistance root-to-shoot transport of phytochelatins and cadmium in Arabidopsis. Proc. Natl. Acad. Sci. USA 2003, 100, 10118-10123. [CrossRef] [PubMed]

56. Lozano-Rodriguez, E.; Hernandez, L.E.; Bonay, P.; Carpena-Ruiz, R.O. Distribution of cadmium in shoot and root tissues of maize and pea plants: Physiological disturbances. J. Exp. Bot. 1997, 48, 123-128. [CrossRef]

57. Jiang, B.; Lin, Y.; Mbog, J.C. Biochar derived from swine manure digestate and applied on the removals of heavy metals and antibiotics. Bioresour. Technol. 2018, 270, 603-611. [CrossRef] [PubMed]

58. Mehmood, K.; Baquy, M.A.A.; Xu, R.K. Influence of nitrogen fertilizer forms and crop straw biochars on soil exchange properties and maize growth on an acidic Ultisol. Arch. Agron. Soil. Sci. 2018, 64, 834-849. [CrossRef]

(C) 2020 by the authors. Licensee MDPI, Basel, Switzerland. This article is an open access article distributed under the terms and conditions of the Creative Commons Attribution (CC BY) license (http://creativecommons.org/licenses/by/4.0/). 